\title{
Enhanced Glucose Electrooxidation at Ni-Cu Binary Oxide Nanocatalyst
}

\author{
Mahmoud M. Abuzaied ${ }^{1}$, Yasser M. Asal ${ }^{1}$,Ahmad M. Mohammad ${ }^{2}$ Islam M. Al-Akraa ${ }^{1, *}$ \\ ${ }^{1}$ Department of Chemical Engineering, Faculty of Engineering, The British University in Egypt, Cairo \\ 11837, Egypt \\ ${ }^{2}$ Chemistry Department, Faculty of Science, Cairo University, Cairo 12613, Egypt \\ *E-mails: islam.ahmed@bue.edu.eg (Islam M. Al-Akraa); ammohammad@cu.edu.eg(Ahmad M. \\ Mohammad)
}

doi: $10.20964 / 2020.03 .57$

Received: 17 November 2019 / Accepted: 21 December 2019 / Published: 10 February 2020

\begin{abstract}
The aim of this study is to fabricate a nickel $(\mathrm{NiOx})$ and copper $(\mathrm{CuOx})$ oxide nanocatalyst on a glassy carbon (GC) electrode (will be abbreviated as $\mathrm{Ni}-\mathrm{Cu} / \mathrm{GC}$ ) for glucose oxidation (GO). A sequential electrodepositon mode was applied to assemble $\mathrm{NiOx}$ and $\mathrm{CuOx}$ in the fabrication scheme. The optimization of Ni loading on the GC surface (will be abbreviated as Ni/GC electrode) was achieved first to attain the maximum catalytic efficiency in terms of the specific current toward GO. This (409 $\mathrm{Ag}^{-1}$ )was obtained by applying $15 \mathrm{mC} / \mathrm{cm}^{2}$ in the deposition of $\mathrm{Ni}$. However, unfortunately the $\mathrm{NiOx} / \mathrm{GC}$ could not support a long-term stability toward GO that motivated a further modification with $\mathrm{CuOx}$ beneath $\mathrm{NiOx}$ (will be abbreviated as $\mathrm{Ni}-\mathrm{Cu} / \mathrm{GC}$ electrode). This modification enhanced the stability toward the GO where the decay in the specific current was not too much compared with that of the $\mathrm{Ni} / \mathrm{GC}$ electrode. After $1 \mathrm{~h}$ of continuous electrolysis, the specific current reached $317 \mathrm{Ag}^{-1}$ at the $\mathrm{Ni}-\mathrm{Cu} / \mathrm{GC}$ electrode compared to $167 \mathrm{Ag}^{-1}$ at the $\mathrm{Ni} / \mathrm{GC}$ electrode.
\end{abstract}

Keywords: Glucose electro-oxidation; NiOx; CuOx; Catalytic activity; Stability.

\section{$\underline{\text { FULL TEXT }}$}

(C) 2020 The Authors. Published by ESG (www.electrochemsci.org). This article is an open access article distributed under the terms and conditions of the Creative Commons Attribution license (http://creativecommons.org/licenses/by/4.0/). 